\title{
学校教育の場における地域用水利用と地域住民意向
}

School Education with Regional Water and the Resident Opinions

\author{
石田害治*・吉村亜希子*・郭 妍**・間中幸子*** \\ Kenji ISHIDA*, Akiko YOSHIMURA*, Yan GUO** and Sachiko MANAKA*** \\ (*農業工学研究所 **筑波大学大学院生命摆境科学研究科 ***明治大学理工学部) \\ (*National Institute for Rural Engineering ${ }^{* *}$ Graduate School of Life and Environmental Sciences, \\ University of Tsukuba ${ }^{* * *}$ School of Science and Technology, Meiji University)
}

I 研究の背景とねらい

国民の価値観の多様化や従来の教科指導偏重 から体験学習へという教育方針の変容のもと で，農業や農村空間の環境資源が教育の現場で さかんに活用され始めている。なかでも農業集 落を流れる用水路の水は，子供たちにとっても 身近な学習素材として重要である。

農業用水や水利施設資源の機能を, (1)用水自 体の機能，(2)用水の制御や管理操作がもたらす 機能, (3)用水や水利施設が位置する空間の機能, に大別すると, 教育の現場で活用されるのは, 主として(3)に属する機能である（表 1 ）。

表 1 農莱用水の多面的な機能の分類

\begin{tabular}{l|l}
\hline \hline \multicolumn{1}{c|}{ 機能の発揮源 } & \multicolumn{1}{|c}{ 具体的な機能例 } \\
\hline (1)用水自体 & 防火,消·流雪 \\
(2)制御や管理操作 & 洪水防止 \\
(3)位置や存在空間 & 親水,社会教育 \\
\hline
\end{tabular}

農業用水は主として潅溉用水として利用され るが，農業集落を流れる過程では，昔から洗い 物などの生活用水や防火用水, 消 - 流雪用水之 しても広く利用されてきた。また，小魚や昆虫 など生物の生息空間や景観の形成にも農業用水 が大切な役割を果たしている。これらの灌溉以 外の農業用水の役割を「地域用水」機能と称し ている。

こうした地域用水としての重要な機能の一つ に, 環境教育活動の場を提供するなどの社会教
育機能の存在が指摘される。また，教員以外の 社会人による授業や体験学習のカリキュラムへ の組み込みなど, 地域社会を学校教育の場とし て積極的に活用しようとする動きの中で，地域 用水の学習教材としての機能が重要視され始め ている。

さらに，文部科学省の学習指導要領改訂に伴 い, 2002 年度より完全実施される「総合的学 習」の対象には,「環境」、「情報」、「福祉」,「国 際理解」の 4 項目が明記されている。この新し い学習指導要領における, 環境を対象とする総 合的学習の展開を，この研究では「環境学習」 と定義し，それに類する教育活動を環境教育活 動と位置づけている。

そして，農業用水が地域用水として利用され ている事例の中で, 花鲑づくりや栽培学習など 学校教育の場における環境教育活動に利用され ている事例を取り上げ，その実態を明らかにす るとともに，社会教育機能の発現に重点をおい て, 地域用水利用を保全するための地域での維 持管理上の課題を考察する。

\section{II 研究の方法と対象地域の概要}

\section{1 アンケートによる地域用水利用の実態把握}

花壇づくりや栽培学習などの環境教育活動に 地域用水を利用している S 県 T小学校を事例と して取り上げ，学校関係者及び用水を管理する 土地改良区の関係者等に対する聞き取り調査及 
び現地踏査を行った。そして，その小学校が位 置する農業集落はじめ通学区内の全農業集落を 対象として, 地域用水利用の実態調查及び環境 学習に利用する水路の維持管理に関する意識調 查を実施した。

特に、下小学校が位置するI集落については， 1999 年 2 月と 2001 年 1 月の 2 回全世帯悉皆乃 ンケートを実施し, $90 \sim 99 \%$ の回収率を得た。 また， T小学校区内の他の 7 集落については, 2001 年 1 月に全世帯悉皆アンケートを行い, 80 〜 97 \%の回収率を得た。いずれも地元関係者 の協力を得て配布・回収する方法をとった。

アンケートにおける主たる設問項目は，(1)用 水の環境学習利用に関する周知状況, (2)蕀境学 習利用の賛否と理由，(3)水路維持管理の支援方 法, (4)維持管理活動への参加意向, (5)水路や用 水の環境学習利用の効果, 等である。アンケー トの回答者は, 男女別にはやや偏りが生じた(男 性 $79.6 \%$ ）ものの, 年齢階層では 50 歳代を最 多に 20 歳代から 70 歳代まで分布していた。

\section{2 対象地域の概要}

対象とした T小学校が位置するI 集落では, 国営農業水利事業により造成された幹線用水路 が流下するとともに, 支線から引水された小規 模な用水路が維横に通っている。伝統と歴史の ある農業集落で, 隣接集落とともに豊かな水路 景観を形成している。

この地域を含むK用水の受益地域（図 1）て は, 1965 年から 1986 年にかけて農業用水の確 保と水利系統の再編を主体とする土地改良事業 が実施されている。この事業では，取水のため の頭首工, 幹線水路, 揚水機場などの施設が整 備され，地域を流れる 3 河川及びY湖（補給用） を水源として, 受益地域の水田地帯に農業用水 が供給され, 地域農業の安定と発展に大きく貢 献した。

その後の営農形態の変化や諸施設の老朽化に 対応して, 補給水確保のための揚水機場の增設 と老朽化水路の更新・改修を目的とする地域用 水機能增進型の国営屡業用水再編対策事業が, 関倸 1 市 7 町の 4,720ha を受益面積として 1998
年から実施されている。

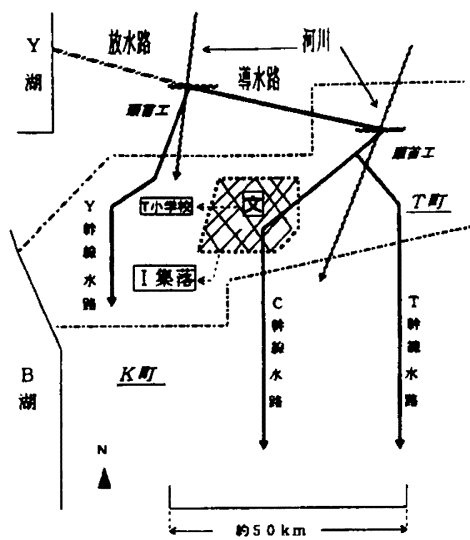

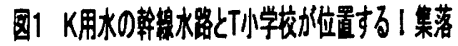

III 農業用水の多目的利用実態と住民 意識

1 地域用水の利用变化に関する全般的傾向

農村地域における混住化の進行に伴い，地域 住民の農業への理解の希薄化が髠念される反 面, 農業用水に期待される役割は次第に多様化 している。鹿業用水の多目的利用の具体的内容 は, 上水道の普及で役割が減少した台所用水等 の生活用水としての利用から防火用水や消雪用 水, 農機具洗い等の中水道的な利用のウェイト が高まりつつある(表 2 ，注 1 ）。

\section{表2 地域用水の利用形態の変化}

\begin{tabular}{|c|c|c|}
\hline 項 & 1965 年 & 1990 年 \\
\hline $\begin{array}{l}\text { 飲み水 } \\
\text { 米とき水·食器洗い } \\
\text { 食物の冷蔵 } \\
\text { 風号水·洗䍜水 } \\
\text { 防火用水 } \\
\text { 消雪用水 } \\
\text { 水車 } \\
\text { 農機具洗い } \\
\text { 水遊び } \\
\text { 魚とり·魚釣り } \\
\text { 庭への引水 }\end{array}$ & 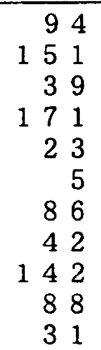 & 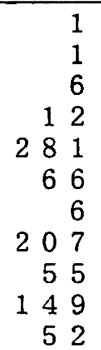 \\
\hline
\end{tabular}

注 : 数字は利用が存在する土地改良区の数。 549 土地改良区対象，複数回答

资料：農林水産省塂造改善局計画調整空调べ（1990） 


\section{2 対象地域における地域用水利用の状況}

アンケートの結果, I 集落における地域用水 利用の主たる内容は,「くつや污れ物洗い」,「消 ・流雪」,「農機具の洗浄」,「野菜洗い」であ ることが明らかになった。図 2 に示したとおり, 「子供の水遊び」なども存在するが，I 集落の 地域用水利用は上述した 4 項目に代表される。 この傾向は, 同じくK用水を受益する周辺の農 業集落にも共通する ”が, I 集落では特に顕著 であることがわかる(図2)。

I 集落では, 住居の数地が水路に面している 場合が多く, $58.6 \%$ の世帯が現在でも専用の洗 い場を有しており,さらに $14.1 \%$ の世帯は最 近まで洗い場を持っていたと回答している。地 域用水利用の阻害要因は,「衛生上の問題」(56.6 \%) と「水質の悪化」(45.5\%) が主である。「上 水道で十分」という回答者も $16.2 \%$ 存在する が, 「水量不足」 $(27.3 \%)$, 「施設・設備の不 十分」（10.1\%）を地域用水を利用しない理由 に指摘する回答者が比較的多いことは, 今後の 地域用水利用の保全には施設整備や利水運用の 改善余地があることも示唆される。

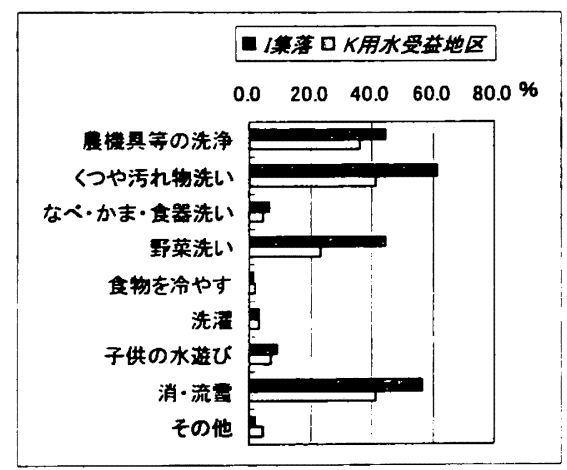

図2地域用水利用の内容

地域用水としての将来的な用途については, 「洗車」(33.3\%) と「教地・道路の清掃」(31.3 \%) が多く，これについては周辺の他の農業集 落での回答傾向 ")とも一致している。

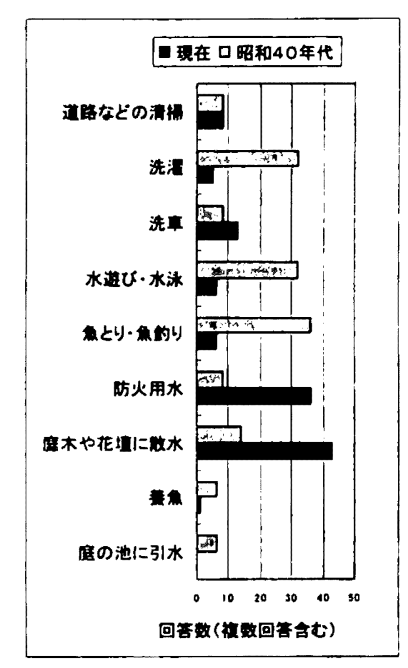

図3 利用内容の变化

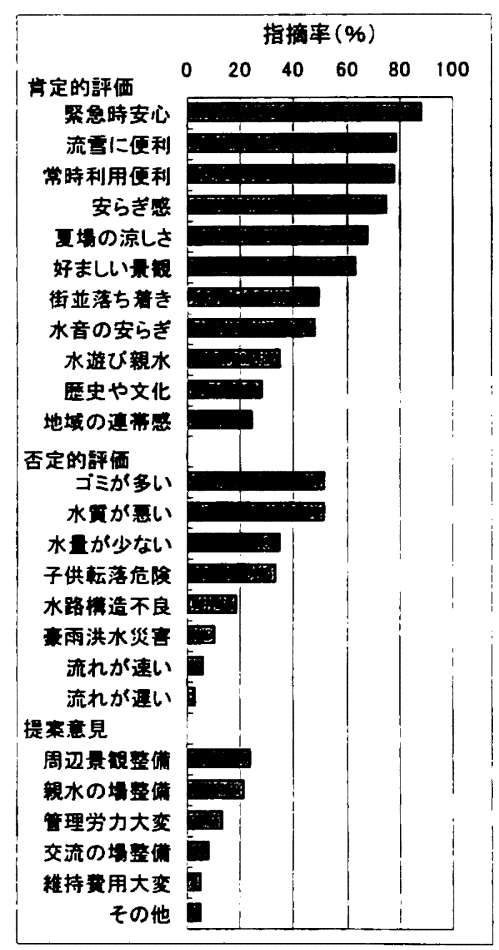

図4㤟業用水に対する住民意撞 
次にI集落における過去と現在の地域用水利 用を比較すると, 図 3 のとおりである。「洗濯」, 「水遊び・水泳」,「魚取り・魚釣り」の項目 は利用が大きく減少している。これに対して,

「防火用水」, 「庭・花壇の散水」の利用は大 きく増加しており,「洗車」利用も増加してい る。こうした傾向を考察すると, 身体が水に直 接触れるような利用形熊，すなわち「接触型」 の利用が減少し、「非接触型」の利用が增加し たと判断される。こうした傾向は，他地区の地 域用水利用の分析結果とも類似している ${ }^{2)}$ 。

\section{3 農業用水の存在に関する住民の意識と評価}

集落を農業用水が流れていることに関する住 民の意識を,「回答件数/総回答者数」を指摘 率と定義して整理すると，図40とおりである。 「緊急時の安心」を首位に, 全般にプラスの評 価がマイナスの評価を上回っている。流雪用水 としての利用や水が常時存在することの防災面 からの評価が高く, 次いで利便性や安らぎ感が 高く評価されている。マイナス面では，「ゴミ が多い」と「水質が悪い」ことが多く指摘され， 次いで「水量不足」, 「子供転落の危険性」が 㦟念事項とされている。

このほか, 用水や水路を取り巻く事項に関す る提案的な内容としては,「周辺景観整備」,「親 水」や「交流」の場の整備が期待されており, 同時に「管理労力」や「維持費用」が慗念され ることが示唆された。

N T小学校における地域用水利用と 環境教育活動

\section{1 水路の親水施設整備と花墥づくり}

I 集落の中心部に位置する $\mathrm{T}$ 小学校では, 全 学年を対象とした総合的学習のテーマに「用水」 を取り上げている。同小学校の显地内を用水路 が通過しており, 水路改修に際して, 览童が 用水を利用しやすいように簡単な施設整備がな された。用水を利用する際の安全な足場ができ たことにより，低学年の児童が利用することも
可能となり，教科の中では全学年が週 1 回〜月 1 回程度、課外活動ではほほ毎日利用されるよ うになった。全校的な取り組みとしては，この 用水を利用して花墥の花づくりを行っている。 この取り組みは，栽培を通じた睘境教育である と同時に，花を育てる気持ちを酸成することに より，命の辛さを学ぶことが意図されている。

\section{2 裳業用水を利用した㻴境学習の展開}

長く取り組まれてきた花壇づくりに加えて, 平成 12 年度から実施されている総合的学習で は, 用水路の生きもの調查などのテーマも設定 され, 平成 13 年度には用水路からの水を利用 した借り上げ水田での米作り体験学習も予定さ れている。農業用水を利用したこれまでの主な 学習テーマやイベント及びその際の用途を順不 同で列挙すると，(1)用具・植木钵洗い，(2)水質 検査, (3)生物観察, (4)へチマ栽培, (5)魚つかみ, (6)散水，(7)干ばつや防火の学習，8地域の水環 境、などとなっている。

こうした学習を通して，児童は，a.水温・水 質・水量の変化, b.水中の生きもの, c.水の使 われ方と廃水，などに大きな関心を示した。ま た，総合的学習の本格化に伴い，用水や水路を 一層活用するためには, $7.20 \mathrm{~cm}$ 程度の水深の 常時確保，1.水路の自然性保全，ウ.小さな殹の 設置、などが教員から指摘された。

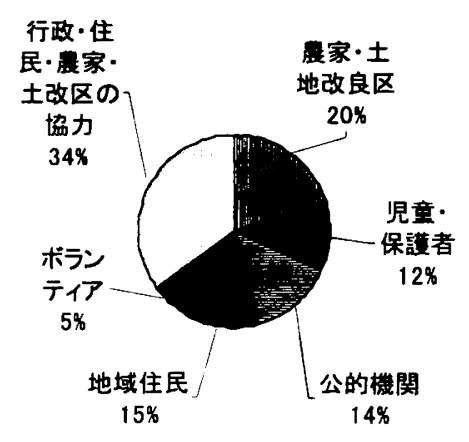

図5期待される維持管理の担い手 （水路や用水を環境学習利用する埸合） 
$\mathrm{V}$ 地域での支援とそれに対する住民 意向

䍗境教育活動に地域用水や水利施設を活用す るためには，水路の清掃など日常的な維持管理 作業や適正な水深, 流速, 水量を確保するため の水利施設の運営などが要請される。現状では, 謴例として地域住民らが水路の清掃などの維持 管理を担っており，翼境学習に要する消費水量 がほとんど無視できる量であることから特段の 問題を生じていない。

T小学校内の水路での環境学習の取り組み を、「詳細に承知している」住民が $17.3 \%$ 「何 となく聞いている」住民を含めると $57.2 \% の$ 回答者が認識していた。農業用水を環境学習に 活用することについては、「農業に妨げになら

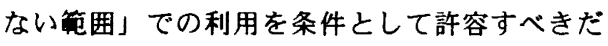
とする回答者数が，積極的に活用するべきだと する回答者数をやや上回った。

さらに，瑟境学習への多目的利用を想定した 場合の水路や用水の維持管理は, 行政・地域住 民・農家や土地改良区が協力して行うべきだと する回答が最も多く（図 5 ), 別の設問では, 維持管理に $71 \%$ の住民の協力が得られる見通 しが確認された。しかしながら，少数意見では あるものの，家族檏成による不公平感や公的機 関の責務を理由とした消極的意見も奇せられて おり, 具体的な協力体制を慎重に構築する必要 がある。

ところで,こうした睘境学習活動の効果に関 する地域住民の意識にも着目する必要がある。 環境学習などに農業用水や水路施設を活用する ことか「児童生徒の農業・農村理解」につなが るかどうかという点については,「好機会」(13.4 \%)とする回答者を含めて, $80 \%$ 以上の回答者 が何らかの効果があると認識している。なかで も「保護者や地域住民の関心の高まり」(28.9 \%)を通じた効果に期待する回答が最も多い。

そこで，この環境学習による具体的な勃果を 検証するため, 学習時間による児童の意識を比 較したところ，4 年生（学習時間 40 時間）と
5 年生（同 12 時間）では, 学習時間が多い 4 年生の方が生きもの発見」や「米作りへの関 心」などに効果が得られていることが考察され た（図6）。

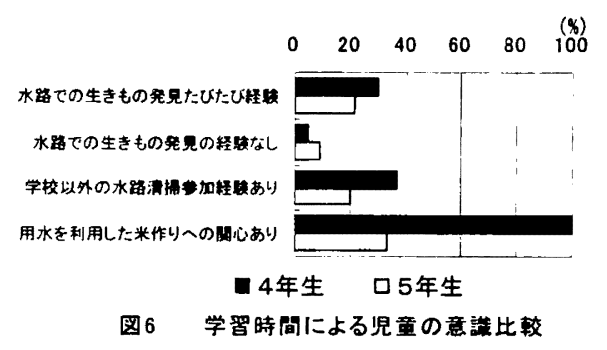

VI 地域用水を利用した環境学習推進 上の課題

アンケートからも明らかになっているよう に, 農業用水の多目的利用は農業生産活動を阻 害するものであってはならない。将来の作付体 系の変化に伴う灌溉利用との競合や水需要の変 化に対応した新たな管理操作の必要性を想定す ると, 維持管理に関する学校関係者と地域住民

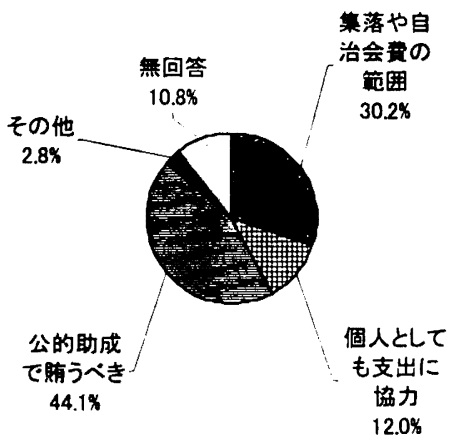

図7 金鉞的支援についての意向

との役割分担や農家及び土地改良区等との関係 を明確化しておく必要があると考えられる。

T小学校の通学区内を対象としたアンケート 調查の結果からは, 「労力の提供には協力でき 
るが，金銭負担を住民に求めるべきでない」 (41.7\%)ことが集約された。また，別の設問で は $44.1 \%$ の回答者は維持管理に必要な経费を 自治体などの公的支援によるべきだとしてお り， $30.2 \%$ の回答者は住民負担を容認しつつも 現行の自治会費等の笵围内であるべきことを指 摘している(図 7 )。

さらに，通学する児童の有無に関わらずに労 力提供を求められることに対して, 不公平感を 抱くという回答も比較的多い $(29.5 \%)$ 。

これらのことから，維持管理活動に関する合 意形成をはかる際の主な要件として，以下の(1) 〜(5)が整理された（注 2)。

(1)行政・地域住民・学校関係者・農家・土地改 良区のパートナーシップを尊重すること。

(2)眎境教育活動に伴う新たな金銭的負担をなる べく住民に求めないよう配虑すること。

(3)参加者に不公平感を生じないよう配虛して維 持管理活動への労力提供を要請すること。

(4)自発的な協力を前提として強制的な義務を発 生させないこと。

(5)教育の場でもある通学区内やその住民と学校 が環境教育活動の情報や水路清掃等の具体的支 援活動において，緊密な連揳をはかること。

また，農業用水を活用した睘境学習を進める 上では，(6)（7)に留意する必要があることが事 例的に明らかにされた。

(6十分な時間をかけて学習対象に接することに より学習効果が向上すること。

(7)児童の農業・農村理解は,「水そのもの」,「水
の中の生きもの」、「水を利用する農業」の順 に学習展開のプロセスとして進展すること。

[注 1]上水道の普及，防火水棈队消防栓等の整備が進 んでいるにもかかわらず，地域用水の防火用水利用が 全国的にも增加倾向にあることの背景には，危機管理 上の観点からも住民要望が大きいこと、コスト負担增 が小さいこと，等があると考えられる。K用水受益地 区では，消防栓など各集落での防火設備の整備と合わ せて地域用水の防火用水利用体制が啫えられた。同地 区では，洗い堨に上水道栓があるなど，上水道と地域 用水が併用されている。

[注2]並行して実施した閔き取り調查では，外部の「企 業・法人」等による支授には否定的であった。また， 地域用水機能全般の維持费用を地域住民による「基金」 でまかなうことについては肯定的であった。

[謝辞]アンケートにご協力いただいた地域住民 の方々ならびに小学校, 土地改良区の関係各位に 深謝の意を表する。

\section{引用文献}

1）石田㗹治（2000）：アンケート調查分析に基づ <地域用水利用の実態, 新湖北地区地域用水機能 增進調查報告書, pp.44-58, 農業土木学会

2)石田鍶治ほか（1998）: 住民アンケート調査に もとづく農業用水の生活用水利用の実熊，農業土 木学会輌要集, pp.764-765.

The social education function is pointed out as one of important functions of regional water, and the community with the regional water is playing an important role in school education. In this paper, we consider the case where the environmental education activities of keeping flower beds and cultivation study are executed by using regional water and canal facilities which locate on the site in the elementary school, and we should clarify the realities of the use. Moreover, we focus on the subjects of supporting these activities that an increase will be expected along with the maturity of integrated study in the elementary education, furthermore the residents' participation in the management problems. 